November - 2007

\title{
Re-organizing Universities for the Information Age
}

\author{
David Annand \\ Athabasca University - Canada’s Open University
}

\begin{abstract}
University education is still generally conducted within pre-Industrial Age organizational structures. As a result of their inability to evolve the predominant cohort-based classroom structure to more cost-effectively meet the aspirations of burgeoning worldwide populations for higher education, universities may see substantial organizational changes imposed on them over the next decades by external forces. Emergent forms of university organizational structures are examined that may affect this needed transformation.
\end{abstract}

Keywords: Fordism; industrialization; innovation; Luddite; university change

\section{Introduction}

Peters (2004) noted that paced, cohort-based education continues to be the norm in both traditional and dual-mode universities, even with the advent of online education. This format facilitates communication among learners and between learner and instructor . Peters noted, however, that expert forecasts of trends in online learning suggest an increasing emphasis on digitized instructional material. As a consequence, learning can be more autonomous and selfdirected. This is similar to the independent study form of distance education more predominant in the European experience. Historically, independent study represents a distinct break with classroom-based academic tradition because it is text-based rather than orally based. It is technically mediated and must be carefully planned and structured. Methods of presenting and acquiring knowledge differ from traditional universities. Learners must organize their learning independently, taking over some of the roles of the instructor. They must be more critically reflective in their learning, as there is little or no external intervention, even with the advent of what Peters describes as 'network-based distance education' - learning that provides access to digital media and the Internet, and allows new forms of learning through searching, evaluating, managing, and retrieving material.

A likely consequence of the increased emphasis on digitized media will be to increase learner demand for autonomy, particularly self-pacing - that is the ability to proceed through a course of studies without reference to a pre-determined schedule or other learners. Despite hopes that social interaction incorporating more characteristics of face-to-face instruction will be facilitated in the 'post-industrial' adult distance education era, facilitating significant learner-to-learner interaction requires cohorts of students to move through a course of studies at the same pace. As a result, requirements of social interaction conflict with learner autonomy. 
Re-organizing Universities for the Information Age

Annand

\section{Theoretical Divide over the Role of Interpersonal Communication}

The imposition of pacing as a necessary precursor for virtually all sustained two-way communication at a distance and the unavoidable restriction on learner autonomy that this produces has been at the centre of a relatively distinct divide among theorists since the 1990s. One view represented by Holmberg (1989) and Keegan (1990) conceptualized the important distinguishing feature of distance education as being organizational forms that facilitate learner independence and autonomy through flexible, self-paced learning. On the other hand, others like Garrison (1997) proposed that the advent of cost-effective two-way mediated communication in distance education had shifted emphasis away from these organizational issues toward the educational transaction itself. Significant and frequent interaction between instructor and learner, and among learners, had become the enabling - if not the essential - learning feature of distance education.

The debate remains unsettled. Operationally, though, organizational issues rather than learning theory significantly determine practice. Underlying beliefs about the relative importance of learner autonomy versus social interaction in the learning process are largely informed by adult educators' experiences within particular organizational structures. Since classroom-based learning predominates in universities, paced, cohort-based forms of learning are almost universally established in the electronic learning environment, as this is easier to support within the processes of the organization. In turn, adult learning theories predicated on paced learning is emphasized. The centrality of human-to-human interaction in current online learning theory like social constructivism exemplifies this phenomenon, even when it is clear that this may not even be the preferred learning mode for adult learners given a choice between self-pacing and group interaction (Anderson, Annand, \& Wark, 2005). To be efficacious, a particular educational theory needs to not only consider pedagogical benefits, but also balance these against learner preferences and perhaps most importantly for the future, relative cost. Replicating paced, cohort-based learning in the virtual environment means that industrialized forms of distance education predicated on independent learning are still largely ignored or disparaged, even though these are scalable and more cost effective.

Anderson (2003) posited the following equivalency theorem:

Deep and meaningful formal learning is supported as long as one of the three forms of interaction (student-teacher; student-student; student-content) is at a high level. The other two may be offered at minimal levels, or even eliminated, without degrading the educational experience. High levels of more than one of these three modes will likely provide a more satisfying educational experience, though these experiences may not be as cost or time effective as less interactive learning sequences. (p. 5)

It is this possibility that one form of learning can be substituted effectively for another, and the resultant need to consider cost/ benefit trade-offs more closely, that should encourage educators to consider more carefully how online learning is organized.

\section{Universities as Pre-industrial Organizations}

Despite growing demand for university education worldwide, and society's increasing desire, directly and through government agency, for increased value for privately and publicly-expended 
Re-organizing Universities for the Information Age

Annand

educational funds, the manner in which most universities conduct central aspects of the education process has not yet been fundamentally altered since pre-modernity. Some writers dispute this. Rumble (1998) noted that during the latter half of the 20th century, traditional universities have grown increasingly large and therefore bureaucratic. This has affected the role of academics, and decreased their ability to influence the learning process. Other factors also affect this role - the 'massification' of higher education; an emphasis on market responsiveness and entrepreneurialism; the rise of a professional managerial class in higher education; and an increasing dichotomy between teaching and research duties. Rumble and Latchem (2004) stated that distinctions between traditional and distance university education have decreased as traditional campuses move to reduce costs - by reducing dialogue between instructor and students (that is, by raising class size) and by imposing more bureaucratic rigour. This reduces the ability to respond to individual student needs. As a result, university teaching has evolved from a communal activity where the worker (academic) directly controlled the process of work, to a more highly organized, bureaucratic process involving many individuals. Effects on academics include de-skilling and loss of control over the educational process - effects similar to those imposed on labourers by the factory system during the Industrial Revolution. In turn, this has led to the diminution of the teaching craft.

These assertions should be challenged, however. Values, processes, and structures underlying the oral, classroom-based educational transaction within universities have not changed for several centuries. Learning continues to revolve around fixed start and end dates, cohort-based learning, and a craft-like approach to learning where one faculty member oversees most aspects of a student's learning experience for a specified time period. The vast majority of universities are still very much vertically integrated organizations with faculty and students clustered on campuses, even with the increasing use of Internet-based learning. Classes are still scheduled to permit a more efficient pursuit of other faculty activities like research and university service. Competitive advantage is often achieved by effectively marshalling faculty resources in one geographical location and by restricting competition through the accreditation process. Though bureaucratic structures have allowed universities to become large and more complex, the fundamental means of learning within the academy has not changed in centuries. In fact, it more closely resembles organizational forms common to merchant capitalism rather than those brought about by the Industrial Revolution.

Merchant capitalism became a significant economic force in Western Europe between the 11th and 16th centuries, depending on region. Merchants acted as intermediaries between buyers and sellers in a relatively straightforward exchange of simple goods and services. They financed their own operations, purchased raw materials, and distributed these to cottage workers. The workers significantly controlled the production process, working independently and at their own pace. Several problems arose with the system. Quality standards and production schedules were difficult to maintain. Increased demand for cloth led to shortages of workers in manufacturing districts and drove up costs. The era drew to a close around 1800, giving way to industrial capitalism and its attendant features - the factory system, incorporation of new technology like steam power and metal machines, and mass production as opposed to artisanship.

In the university, however, these industrializing characteristics were largely eschewed in favour of tradition. Most technological advances of the day could not be adapted easily to the classroom. Perhaps more fundamentally, growing direct public funding of universities insulated the academy from these industrializing effects. The exception to this was the formation of dedicated distance education universities. Peters (1983) argued that first and second generations of distance education introduced industrialized processes to adult learning starting as early as the mid-1800s. 
Re-organizing Universities for the Information Age

Annand

These processes included division of labour, managerialism, mechanization, capital-intensive technology, and an assembly-line mindset. Instructional tasks like curriculum design, content preparation, student support, formative assessment, and examination were divided up so that these could be undertaken by different people. Relying first on printed instructional packages and later digitized instructional media, industrialized forms of distance education became less subjective and craft-like than traditional, classroom-based university education.

Though followed by other phases, it is these industrialized characteristics that remain at the core of what Taylor (2001) described as the most recent incarnation of distance education, a fifth generation he dubbed 'Intelligent Flexible Learning.' Besides the relatively commonplace features found in most online learning systems, fifth generation distance education also incorporates business technologies that streamline instructional material production and student service functions. These permit multiple types of media outputs from a single source document, and provide student access through online portals to automated business processes and academic advice, for example. Most importantly, individually tailored services can be provided to an increasing number of learners with the same economic resources by using knowledge management software to reduce the need for direct, human interaction in the teaching and learning process. As Adria and Chowdhury (2002) noted, these software capabilities can be further leveraged by reassigning duties traditionally performed by academics, like student advising and general administrative information, to Call Centre personnel.

Critics of all forms of industrialized distance education term it 'Fordist,' and disparage it as a valid educational form, and generally consider it antithetical to desirable teaching and learning processes. As Stevens (1996) observed, its practitioners are accused of neocolonialism because it is purported to exclude, marginalize, and objectify learners and educators, to provide tacit support for globalization, and to diminish the teaching craft. Even post-Fordist paradigms that make industrialized education processes more flexible and humane, have not adequately nor fundamentally addressed the deficiencies of Fordism.

The problem with most criticisms leveled against industrialized distance education is that they can be applied equally to any form of university organization. Tendencies to be influenced by technology-based knowledge interests and politically motivated bureaucracies are certainly not unique to industrialized distance-based universities. The unexamined massification of both distance and campus-based higher education can result in the objectification of students. Education for transformation and democratic participation are principles embraced, and as a result, such practices are incorporated into the teaching processes of some faculty within industrialized distance education institutions, as well as at conventional campuses, albeit only sometimes for the latter. Niche marketing of university degrees, particularly in foreign jurisdictions, is practiced by a number of campus-based universities with physical presences in these offshore locales.

Furthermore, faculty in both classroom and distance-based university education often welcome the assignation to more mundane academic duties, like marking. Faculty at traditional universities moving into online education often benefit from the use of instructional designers, graphic artists, and editors, who contribute expertise to the online course production processes. It is the increased possibilities of instructional media and communications within the electronic environment that requires additional expertise, and this need not strip academics of their core academic responsibilities even in an industrialized setting. 
Re-organizing Universities for the Information Age

Annand

The opposition to industrialized distance education echoes sentiments voiced by Luddites as the textile industry of England evolved into the Industrial Age, and gives credence to the suggestion that most universities' organizational forms pre-date the Industrial Revolution. The Luddite rebellion of the early 19 th century was an organic and spontaneous movement based in the English Midlands. It is estimated that there were, for instance, 100 to 150 "General Ludds" leaders of small bands of insurrectionists. The rebellion took place primarily in three counties Lancastershire, Yorkshire, and Nottinghamshire - and at various times during the years 1811 and 1812. The large geographic size of the affected English countryside, and the fact that communication was by word of mouth, makes the organization and coordination of the rebellion even more remarkable. Groups of loosely organized cottage-based textile workers destroyed large stocking frames housed in textile factories and in the homes of several master craftsmen. These machines produced less-expensive stockings than those produced by skilled home-based knitters. Despite the generally pejorative tone now attached to the term, Luddites were overall an intelligent, well-disciplined, courageous group of people who acted on their convictions and at their own peril. They were not bungling Neanderthals as they are now often portrayed, but the focal point of the collision of old and new value systems created by emergent industrialization.

As Kennedy (1997) opined, and contrary to popular perception, the Luddites' destruction of certain types of machinery was a means to maintain a culture rather than a labour tactic. Luddites were not opposed to mechanization in all its forms. They embraced technology that reduced toilsome aspects of work, or enhanced output and quality of goods in their cottage-based industry. They identified with the past, and had a strong sense of relationship and community within their villages. They were opposed to technology that forced people into factory servitude, replaced workers with machines, deprived artisans of pride in their skills, produced allegedly inferior products, abolished set prices, and introduced free markets.

Neo-Luddites in the academy may have the same desire to control the nature of change in their work environments. A sense of loss of craft, fear of dislocation for students and faculty, and an assumption that re-organization may break down the bonds of academic community and result in the loss of control over the educative process seems to significantly inform today's opposition to some forms of technological change within the academy. If people matter more than technology, and machines are useful only if they contribute to a greater human (rather than economic) good, changes that are perceived threats to these ideals are opposed.

\section{The Innovation Imperative}

These sentiments have been amply reflected in the literature. The larger question is whether the perceived negative effects are probable, and if not, whether the academy can successfully resist the industrialization of higher education. Perhaps they can. Faculty associations and academic decision making bodies continue to hold considerable influence and are invariably a voice for incremental reform rather than radical restructuring. Continued evolution to cohort-based online learning at traditional universities may reduce the need for expensive physical infrastructure and thus reduce overall costs and external pressures to re-organize.

Realistically, though, most publicly funded universities still appear unwilling or unable to change the way that they operate in any fundamental way. Publicly funded universities in particular are generally ill equipped to handle major organizational change in almost all countries. At the same time, capacity constraints are becoming more severe because of serious, deepening shortages of academic and professional staff in developed countries' universities. Where university access is less problematic, classroom space is limited and infrastructure is aging. 
Much like the Industrial Revolution before it, rapid technological change in the Information Age has to date created significant, fundamental change in virtually all sectors of society except education. This may not remain the case for long. A confluence of factors puts increasing pressure on university systems worldwide to change.

Dhanarajan (2001) estimated that there are over three billion adolescents and adults who are under-literate, illiterate, or in need of retraining. Moe (2002) reported that there are only 10 countries that presently provide higher education to one-third or more of their college-age populations. Demographics indicate that absolute numbers of students, the number of students as a percentage of total population, and average age of students, will increase over the next 25 years. Population growth, increased economic activity, and growing demand for white-collar workers will create an unequalled demand for higher education. Based on much the same data, Daniel, Kanwar, and Uvalic-Trumbic (2006) predicted that a 'tectonic shift' will transform the map of higher education worldwide - the growth of universities in the developing world. Spreading connectivity allied with the massive creation of open-source educational resources may soon allow economies of scale and the attendant radical reduction in costs necessary for higher education to serve the four billion people at the bottom of the world's economic pyramid.

The missing factor in this analysis, however, is the need for university re-organization. Taylor's fifth generation learning model may replicate in the virtual learning environment two key attributes that accounted for the initial successes of distance education - flexibility for students and value creation for the institution, primarily in the form of reduced costs and enhanced services (as compared to traditional, campus-based universities). To the extent that Anderson's (2003) equivalency theorem holds, a less recognized corollary of Taylor's (2001) analysis is that universities incorporating high-quality digitized instructional media into well-structured learning experiences also can disaggregate student cohorts in favour of individualized learning and still provide focused group interaction for specific purposes within a self-paced learning experience. In this way, economies of scale can be realized, costs can be reduced, the overall quality of the learning experience can be maintained, and more learner autonomy can be facilitated. Most importantly, technologically-enabled, industrialized, yet responsive organizational structures can be established to meet the future demand for university education.

The public university sector could be radically altered by this combination of environmental pressures and new possibilities for organizing, particularly when understood in the context of innovation theory. According to Christensen and Raynor (2003), disruptive innovations occur when a simpler, more convenient, or less expensive product that may appeal to a new or previously unattractive customer base is introduced, generally by a new entrant in the market. This type of innovation also gradually pulls customers away from existing firms, starting with those who are most easily satisfied. The disruptive business model succeeds because the higher volumes of customers that are created by innovative, less costly approaches allow reasonable returns to be earned at lower prices by new firms.

Three litmus tests were proposed to determine whether an idea has disruptive potential. First, does the product or service appeal to a large group of people who previously have not had the money, equipment, or skill to use the product or service, or who have to travel to inconvenient locations? Second, is there a group of people at the low end of the market who would purchase the disruptive technology if it costs less, even if performance might be lower but still acceptable? Third, does the innovation disrupt all firms in the industry? Though Christensen and Raynor (2003) deal with innovation in a free market economy, this phenomenon is equally valid in any system where resources are scarce and good financial stewardship is required - for example, in 
Re-organizing Universities for the Information Age

Annand

the state-funded higher education sector. In this particular example, innovation permits the same level of resources to be allocated more efficiently to serve a larger number of students, or allows tuition to be reduced.

Historically, distance-based universities would almost certainly qualify as disruptive innovators, given their lower cost structure and flexibility that appeals to learners who can not attend traditional universities because of work, family, or other commitments. This advantage is not negated even with the introduction of Web-based learning in virtually all universities. In the electronic age, campus-based universities and even dedicated distance education institutions that do not take advantage of less expensive and newer organizational forms and operational processes now made possible by rapid improvements in the electronic technologies of fifth generation distance education, risk being supplanted by a few online university education providers that can get the model right.

Van Dusen (2000) used the term 'millennial restructuralism' to describe a view whereby radical restructuring of the academy is necessary to respond more rapidly to changing social, demographic, and economic pressures. A necessary component of this view is the removal of traditional constraints of learning - time and place. Concomitantly, new learning technologies adopted by appropriately reorganized institutions should be used to create significantly new approaches to the process and management of higher education, and not merely augment the classroom-based, faculty-centred model of most university education.

Unfortunately, a s Hilsberg (2004) noted, new technologies are considered within most universities only to the extent that they might incrementally improve the cohort-based, paced educational process in both traditional and online environments, without regard for how technology coupled with organizational reform might transform the educative process. Research conducted by Irele (2005) identified major issues and challenged the assumption that online education could be widely accepted and integrated into the mainstream of higher education. Peters (2004) provides further insight into the tensions that arise when distance education systems are introduced within traditional universities. He stated,

They have to deal and come to terms with fixed academic structures and conventions which are normally resistant to change and restrict flexibility. They have to assert themselves when trying to innovate and modernize not only the learning-teaching system, but also the mission and the sense of direction of the institution in order to adapt it to the requirements of a rapidly changing society. (p. 146)

\section{Prognosis}

It is these generally inflexible characteristics of the traditional academy that do not bode well for its future. It seems clear that growing demand for higher education cannot be met within a controlled paradigm like the present, conventional university system. This when combined with a worldwide entrepreneurial culture, the growing correlation between education and quality of life, and the increasingly strategic role of knowledge in determining the prosperity and security of nations, threaten the virtual monopoly of not-for-profit universities over the certification of higher learning. This would be unfortunate. It is quite possible to envision universities where technologically-facilitated educative processes are structured in significantly different, less expensive, and yet still-effective ways, but where academic freedom and research remain highly valued. These attributes can be maintained by retaining the autonomous, faculty-centred governance structures of publicly funded, not-for-profit universities; by strengthening the role of 
Re-organizing Universities for the Information Age

Annand

regional and national accreditation bodies; and by encouraging continued state funding of higher education. In effect, these measures retain barriers to entry from private competitors in the interest of supporting the demonstrable public good of publicly funded, research-supporting universities.

The generally silent struggle underway within the academy to determine the appropriate means to employ technology - using it to either fundamentally change the way education is delivered to students, or using it to augment the traditional way that higher education has been conducted by replicating the classroom in an electronic environment - is far from resolved. If creatively implemented, significant transformative change may be realized within current academic structures. However, heightened aspirations of a burgeoning world population, coupled with a growing perception that development of more affordable, widely-accessible education systems is desirable because civilized societies should provide their citizens with the education they need throughout their lives, create pressure on the academy to change perhaps too quickly. It is still unclear whether resistance to change within the academy constitutes anything other than rearguard action. Irresistible technological, economic, and social imperatives seem about to impose significant change on the conduct of higher education worldwide.

\section{References}

Adria, M., \& Chowdhury, S. (2002). Making room for the call center. Information Systems Management, 19(1), 71-80.

Anderson, T. (2003). Getting the Mix Right Again: An updated and theoretical rationale for interaction. The International Review of Research in Open and Distance Learning, 4(2). Retrieved January 27, 2007 from: http://www.irrodl.org/index.php/irrodl/article/view/149/230

Anderson, T., Annand, D., \& Wark, N. (2005). The search for learning community in learnerpaced distance education programming or "Having your cake and eating it, too!" Australian Journal of Educational Technology, 21(2), 222-241. Retrieved January 27, 2007 from: http://www.ascilite.org.au/ajet/ajet21/res/anderson.html

Christensen, C., \& Raynor, M. (2003). The Innovator's Solution. Boston: Harvard Business School Press.

Daniel, J., Kanwar, A., \& Uvalic-Trumbic, S. (2006, July/ August). A tectonic shift in global higher education. Change. Retrieved January 27, 2007 from: http://www.carnegiefoundation.org/change/sub.asp?key=98\&subkey=1841

Dhanarajan, R. (2001). Distance Education: Promise, performance and potential. Open Learning 16(1), 61-68

Garrison, R. (1997). Computer Conferencing: The post-industrial age of distance education . Open Learning, 12(2), 3-11.

Hilsberg, T. (2004). Comments in closing ICDE plenary session. 21st ICDE World Conference on Open Learning \& Distance Education, February 20-24, 2004, Hong Kong. 
Re-organizing Universities for the Information Age

Annand

Holmberg, B. (1989). Theory and practice of distance education. London: Routledge.

Irele, M. (2005). Can distance education be mainstreamed? Online Journal of Distance Learning Administration, 8(2). Retrieved January 27, 2007 from:

http://www.westga.edu/\%7Edistance/ojdla/summer82/irele82.htm

Keegan, D. (1990). The foundations of distance education (2nd ed.). London: Routledge.

Kennedy, P. (Producer). (1997, Feb. 17). Luddites and friends. Ideas [Radio Program]. Toronto: Canadian Broadcasting Corporation. Retrieved November 8, 2007 from:

http://www.cbc.ca/ideas/features/luddites/index.html

Moe, M. (2002). Emerging Trends in Post Secondary Education -The view to 2012. Driving Post-Secondary Education Conference. Washington, DC. December 9, 2002. Retrieved January 28, 2007 from: at http://www.usdla.org/ppt/THINKEQUITY.ppt

Peters, O. (2004). Distance Education in Transition. New trends and challenges (4th ed.). Oldenburg : Bibliotheks-und Informationssytems der Universitat Oldenburg.

Peters, O. (1983). Distance teaching and industrial production: A comparative interpretation in outline. In D. Seward, D. Keegan, and B. Holmberg, (Eds.), Distance Education: International perspectives (pp. 95-113). New York: Routledge.

Rumble, G. (1998). Academic Work in the Information Age: A speculative essay. Journal of Information Technology for Teacher Education, 7(1), 129-145.

Rumble, G., \& Latchem, C. (2004). Organisational models for distance and open learning. In H. Perraton and H. Lentell (Eds.), Policy for open and distance learning. London:

RoutledgeFalmer.

Stevens, K. (1996). Have the shifting sands of Fordism resulted in ground lost or ground gained for distance education? Distance Education, 17(2), 247-266.

Taylor, J. (2001). Fifth Generation Distance Education. Keynote Address presented at the 20 th ICDE World Conference, April, 2001, Düsseldorf, Germany.

Van Dusen, G. (2000). Digital Dilemma: Issues of access, cost, and quality in media-enhanced and distance education. San Francisco: Jossey-Bass.

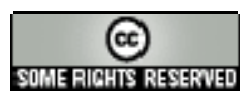

